\title{
Achievement to Sustainable Urban Development using City Development Strategies: A Comparison between Cities Alliance and the World Bank definitions
}

\author{
S. Mostafa Rasoolimanesh (Corresponding author) \\ School of Housing, Building, planning \\ Universiti Sains Malaysia, 11800, Penang \\ Pulau Pinang, Malaysia
}

Tel: 60-17-661-7503Ｅ-mail: rasooli1352@yahoo.com

\author{
Nurwati Badarulzaman \\ School of Housing, Building, planning \\ Universiti Sains Malaysia, 11800, Penang \\ Pulau Pinang, Malaysia
}

Tel: 60-4-653-3888 Ext 2504 E-mail: nurwati@usm.my

\author{
Mastura Jaafar \\ School of Housing, Building, planning \\ Universiti Sains Malaysia, 11800, Penang \\ Pulau Pinang, Malaysia \\ Tel: 60-4-653-3888 ext: 2827 E-mail: masturaj@usm.my
}

Received: July 15, 2011

Accepted: August 9, 2011

doi:10.5539/jsd.v4n5p151

\begin{abstract}
The term "sustainability" has been used in various forms and definitions. The earliest use of "sustainability" or "sustainable development" can be traced back to 1972. In order to cope with four decades of global economic, social, and environmental challenges, sustainable development was adopted as a mantra by international agencies, national and local governments, especially after Habitat II in the local level. On the other hand, new approaches in urban planning were employed in order to achieve a sustainable development. To this extent, City Development Strategies, conceived as strategic planning approaches, were established in 200 cities worldwide. However, City Development Strategies and sustainable urban development are defined in many different ways; furthermore, City Development Strategies enjoy different levels of success in the area of sustainability. This paper compares two specific definitions of City Development Strategies brought forward by cities Alliance and the World Bank in order to achieve sustainable development.

Keywords: Sustainable urban development, City development strategies, Urban planning, The world bank, Cities alliance, Developing countries

\section{Introduction}

In the past four decades, cities around the world had to face economic, social, and environmental challenges, as well as fast urban changes, such as rapid population growth and social-spatial changes. These factors have had a significant impact on urban areas in the developing countries (UN-HABITAT, 2009). As of today, around 75 percent of the global population growth is concentrated in developing countries. Nearly 40 percent live in cities, being this estimate expected to reach 52 percent by 2020 and, eventually, 67 percent by 2050(UN-HABITAT, 2001, UNDP, 2003). Such changes are affecting the areas of economy, social condition, and environment. Economic uncertainties and the competition in the attraction of investors are the major results of these changes. Another considerable consequence is the focus on democracy, decentralization, and governance to promote the
\end{abstract}


relationship between citizens, the private sector, the civil society, and the government. Other issues such as the climate change and energy consumption are also affecting urban areas. Consequently, cities around the world have to cope with the impacts of i) globalization, ii) decentralization of responsibilities, and iii) a rapid population growth (Cities Alliance, 2005). Changes in economic institutional structures, civil society, and in the form and scale of environmental and conflict-related challenges have had a strong impact on the urbanization and the urban growth, as well as on the socio-spatial dynamics in urban areas.

On the one hand, local governments need to promote urban economic competitiveness; conversely, they also have to deal with the impacts of globalization in the form of such social problems as urban poverty, unemployment, and rapid population growth (Watson, 2009). Nevertheless, their efforts are often stonewalled by the lack of finances and by certain restrictions imposed the on local governments (Beall, 2002). The concept of sustainable cities and sustainable urban development was advanced to help cities cope with these challenges. This definition of sustainability was postulated in 1972 at the United Nations Conference on the Human Environment in Stockholm, and was further brought forward during the Habitat I in Vancouver in 1976.. Additionally, in 1992, , the Agenda 21 was approved for the purpose of promoting Sustainable Human Settlement Development during the United Nations Conference on Environment and Development. Ultimately, during Habitat II in 1996, the Local Agenda 21 (LA21) was implemented in urban areas (Whitehead, 2003).

The major goal of sustainable development is to strike a balance between the economic, environmental, and social necessities. In order to achieve a sustainable urbanization, cities need to develop social and economic structures without damaging the environment, and achieve a balance between the human inhabitants and the natural resources (Abu-Ghazalah, 2008). This balance can be achieved by employing a system combining the participation of citizens and scientific knowledge provided by scientific analysis (Jepson, 2001 as cited in Roy, 2009). In this system, sustainable urban development is considered "as a new large-scale vision to guide the planning agenda for the twenty-first century” ( Saha \& Paterson, 2008, p. 22)

The nature of planning in order to cope with the $21^{\text {st }}$ century's challenges and to achieve a sustainable urban development is different when compared to older approaches. Urban areas are complex and are constantly changing. Many cities in the developing countries have older forms of planning, and are surrounded by large informal settlements or slums (UN- Habitat, 2009).

Urban planning is therefore considered as a tool trying to translate vision to priorities in order to lure investment, upgrade urban areas (especially slums or informal settlements), encourage infrastructure investments, and regulates land use. Planning may also be considered as governance based on participation. Therefore, planning is not a neutral technical exercise, and mainly depends on the making of ethical decisions (Healey, 2004).

Considering the unprecedented challenges facing $21^{\text {st }}$-century cities, the new approaches to urban planning need to be able to handle such problems and thereby achieve a sustainable urbanization. These approaches should be strategic in order to cope with changes, uncertainties, and the complex challenges facing modern cities. Unfortunately, older approaches to urban planning, such as master plans and comprehensive plans failing to address the new challenges in cities, are in some instances directly contributing to the aggravation of poverty and spatial marginalization in many parts of the world (UN-HABITAT, 2009).

City Development Strategies (CDS) is an urban strategic planning approach initiated in East Asia by the World Bank in 1998 in order to attain sustainability in cities, and has four major themes, namely: livability, competitiveness, good governance, and bankability (The World Bank, 2000). CDS is employed by Cities Alliance and its member organizations, such as the World Bank, UN-Habitat, Asian Development Bank (ADB), and others, and has presently been adopted by 200 cities around the world. CDS helps the improvement of local economies, reducing urban poverty by developing strategies, and enhances local governance. It also bridges the gap between sustainable urbanization goals and local objectives and priorities (ECON \& CLG, UTS, 2005). CDS is a dynamic and flexible process that responds to opportunities and faces urban challenges and developments (ADB, 2004).

This paper aims to discuss CDS' themes and contents; introduce the characteristics of sustainable urban development; and compare such characteristics in order to evaluate the proportion of achievement sustainability achievable with the CDS' employment. (as illustrated in Figure 1) However, CDSs have many definitions, especially regarding the contents and themes concerned, and enjoy different levels of success in the area of sustainable development. Different concepts of sustainable urban development are now being adopted in different countries. In this paper adopted two specific definitions of CDS brought forward by the World Bank in 1998 and the Cities Alliance in 2006, and a specific definition of sustainable urban development as presented by Saha and Paterson (2008). This paper discusses which definitions of CDSs pertain a higher level of sustainable 
urban development's achievement.

\section{Sustainable urban development definitions and concepts}

The concept of sustainability was coined in 1972 at the United Nations Conference on the Human Environment in Stockholm (Whitehead, 2003). This definition was also used in 1992 during the United Nations Conference on Environment and Development in Rio de Janeiro, approving the Agenda 21 in order to promote Sustainable Human Settlement Development; it was further employed in 1996 during the Habitat II, focused on the implementation of the LA21 in urban areas (Whitehead, 2003).

Sustainable development as a concept is a response to the challenges facing urban areas, such as globalization, decentralization, and rapid population growth. These changes affect such matters as the economy, the social conditions, and the environment, and bring about problems recognized as social inequalities, slums or informal settlements, and climate change. Sustainable development is meant to resolve the economic, social, environmental, and governance issues in an urban setting (Malkina-Pykh, 2002). However, a clear definition or conceptualization of "sustainable development" (which has more than 200 definitions) is still vague (Parkin, 2000 as cited in Keivani, 2010). A review of its definitions often brings to light the problems it should respond to; nevertheless, such factors are so broad that it is hard to grasp the actual concept (Saha \& Paterson, 2008).

There are two categories of sustainability in an urban area, namely, i) urban sustainability or sustainable city and ii) sustainable urban development or sustainable urbanization. The terms "urban sustainability" and "sustainable city" may be used to define the proper use of resources, the protection of the natural environment, the least possible use of non-renewable resources, and the economic growth or a community's self-confidence, individual welfare, and the satisfaction of basic human needs (Shen et al., 2011, Roy, 2009). According to the United Nations Sustainable Cities Programme, a sustainable city has continuing natural resources upon which its development depends. A sustainable city is free from any environmental issues that may threaten its development (Whitehead, 2003). According to Whitehead (2003, p. 1188), "the sustainable city represents an economic space within which the social, economic and ecological contradictions of capitalism are being managed and strategically addressed". On the other hand, sustainable urbanization and sustainable urban development apply to a dynamic process geared towards achieving suitable conditions that address environmental, economic, social, and governance sustainability concerns (Shen et al., 2011; Roy, 2009).

Sustainable urban development, as a process, creates a balance between economic, environmental, and social necessities. To apply such balance locally, the Local Agenda 21 (LA21) was proposed at the United Nations Conference on Environment and Development (UNCED) in 1992. LA21 is "an agenda that sets tasks and a vision in order to promote sustainable development at the local level and shows the menu of action" (Nakaguchi, 2004, p. 28 as cited in Tonami \& Mori, 2007). According to LA21, sustainability has four dimensions, namely; social, economic, environmental, and institutional or governance aspects (Spangenberg et al., 2002). The World Bank (2000) has described the process of sustainable development's achievement in cities, indicating that cities must be livable, competitive, properly governed, and bankable.

In other words, to do this, cities should achieve social and economic advances without damaging the natural environment. This balance can come about by using a smart system that combines the above aspects in order to achieve an urban vision. Urban planning is a traditional tool in striking a balance between these different aspects, and promoting interaction between and among city planners, officials, and the local community (Diamantine \& Zanon, 2000).Urban planning plays a key role in sustainable urban development. The goal of sustainable urban development is the creation of an equal balance between the economic, environmental, social, and governance aspects, in order to create more livable and productive cities, towns, and villages (UN-HABITAT, 2009) by using methods that require the participation of decision makers and stakeholders and new tools to enable decision makers to respond properly(Malkina-Pykh, 2002). City planning tools are used in the evaluation of the social, economic, and environmental impacts of urban policies. They allow for a systematic analysis of the relationship between social, economic, and environmental developments, which describes the mutual dependence between city planning and sustainable development at the strategic and operational levels (Rotmansa et al., 2000). As such, city planning should be based on the principle of sustainability, in order to achieve sustainable urban development.

An appropriate sustainable urban development planning should be a response to the global changes and trends affecting cities, especially in the developing countries. Those strategic urban planning systems developed in the past decades consisted of frameworks linked with a set of indicators which evaluated the sustainability of city's policies (Rotmansa et al., 2000). This paper explores to what extent the principle of sustainable development has been applied to CDS. However, it is important to identify which definition of sustainable urban development 
should be employed.

In the developed and developing world, much research has attempted to clarify the concept of sustainable urban development and to answer the question: "how can we implement sustainable development in cities?" (Saha \& Paterson, 2008; Keivani, 2010). This concept seems however very vague still. Some researchers demonstrated the existence of more than 200 different definitions of "sustainable urban development" (Keivani, 2010). However, among all of these definitions, Saha \& Paterson's study has tried to evaluate the commitment of the principle of sustainable urban development in planning activities. Therefore, this definition seems to be appropriate for the comparison between two CDSs as defined by the World Bank and Cities Alliance for the achievement of sustainable urban development.

Saha and Paterson (2008), when reviewing Protney (2003), Jepson (2004) and Conroy (2006), have identified the four aspects of sustainable development as i) Environmental Protection, ii) Economic Development, iii) Social Equity, and iv) Administration and Governance. These four studies employed sustainable activities to evaluate local governments and cities' plans for sustainable development. In this regard, Portney (2003) identified thirty-four activities, while Jepson (2004) defined thirty-nine. On the other hand, Conroy (2006) selected sixteen, and Saha and Paterson (2008) defined thirty-six (as illustrated in Table 1). Some of the activities overlapped with each other. The studies conducted by these researchers may be considered in the evaluation of CDS and sustainable development, because they have explored the relationships between sustainable development and planning.

Furthermore, Portney identified twenty-three activities related to environmental protection, arguing that activities related to economic development could also help to bring about environmental sustainability; nevertheless, Portney did not indicate activities related to social equity. Portney's study concentrated on the governance aspect of achieving sustainability. Portney's work mostly focused on the environmental dimension and such other dimensions that help to bring about environmental sustainability. However, it appears that such dimensions do not strike a balance among and between all aspects of sustainable development.

On the other hand, Jepson defined twenty-two activities related to the environmental dimension, twelve related to the economic dimension, and five related to the social equity dimension. Jepson's study paid attention to the economic and social aspects more than Portney's, and improved the balance between the aspects of environmental, economic development, and social equity. Furthermore, while Jepson failed to take into account in his study, Conroy also defined public participation and regional coordination as governance activities, .Ultimately, Saha and Paterson (2008) combined the approaches of earlier research and focused on eleven activities related to economic and social equity. According to Saha and Paterson, economic activities help creating a sustainable environment, but are unhelpful in the creation of economic development. Nevertheless, some activities may move towards economic development. The strong points of this research are the attention to low-income, homelessness, and poor people on one hand, and to women, the youth, and minority groups on the other. However, this research did not focus on the governance aspect, but on three aspects only, namely; environmental protection, economic development, and social equity. Saha and Paterson's work was more comprehensive than other early researchers' studies. We can select Saha and Paterson's study in three aspects, and complete their study on the aspect of governance by incorporating Portney's study, thus creating a framework with a total of forty-two activities to evaluate the sustainability of CDSs.

\section{What is City Development Strategies (CDS)?}

City Development Strategies (CDS) in developing countries was started in 1998 in East Asia based on the World Bank's draft urban strategy paper (UN-Habitat, 2002). It focused on four common themes, namely; livability, competitiveness, good governance, and bankability to achieve sustainability in cities (The World Bank, 2000). CDSs were initially implemented in Indonesia, the Philippines, Thailand, Vietnam, and China. The World Bank (2000, p. 15) mentioned city strategy exercises as a participatory process "that would outline the stakeholders' vision for the city, analyze the city's prospects for economic development, and identify priorities for action to implement the strategy. City strategies would focus on the issues of greatest local concern for livability, and the requirements for enhancing city productivity, management, and financing."

When Cities Alliance was founded in 1999, poverty reduction became one of the fundamental objectives of CDS. Cities Alliance and its member agencies, such as the World Bank, UN-Habitat, and Asian Development Bank (ADB), promoted and funded CDS. CDS promotes local economies and helps reducing poverty by developing strategies and by enhancing local governance. It also helps building a bridge between sustainable development, and local objectives and priorities (ECON \& CLG, UTS, 2005).

According to ADB (2004, p.5), "A CDS focuses on the process of change, highlights urban dynamics and 
opportunities, and adopts a flexible strategy for responding to economic realities within a competitive environment. It also helps to build stakeholder capacity to manage a city more efficiently and to encourage and attract businesses in national and global markets. It does this by encouraging stakeholder participation and empowerment. Thinking about the future within a CDS framework often changes the way that a city is managed and planned."

Developing cities in a competitive and unpredictable economic condition need effective methods to properly use limited financial and human resources. If the economic condition is right, cities can attract capital and businesses. An effective CDS attracts capital and makes proper use of it (Cities Alliance, 2006a). CDSs, through comprehensive action plans, should focus on improving urban governance, financial responsibility, and the foundation of clear priorities for action and investments. The development strategies are based on an assessment of each city's economic growth prospects and are aimed at enhancing its competitiveness (Mukhija, 2006).

CDS is a process planned by local stakeholders to formulate a vision for their city through a participatory process. This involves viewing and analyzing the city's plans for development, the recognition of priorities for investment and development, and the implementation of the city's vision through partnership-based approaches (Kim, 2002). However, CDS processes in developing cities differ from the developed ones. Therefore, different strategic reactions are needed. Conditions differ between very poor developing cities, such as Bamako in Africa, and transitional-economy cities as Prague and Sofia, including soon-to-be-rich cities, such as Chengdu in China. Developed cities use CDSs to promote their competitiveness, livability, and so on. These cities have a long history of strategic planning to achieve their goals. Although CDSs differ between developed and developing cities, they do not differ in the technical processes and products, the access to financial resources, the comparative urban experiences, and the knowledge resources, such as consultants, universities, and international organizations (Cities Alliance, 2006b).

CDS approaches develop from Michael Porter's research, which suggested that economic development strategies should be based on the competitive advantage of cities and regions, and should allow for a more active role of the private sector, with a significantly reduced governmental involvement. In this regard, many scholars disagree and argue that governments are more likely to have a more involved role in the successful economic development (Fainstein \& Gray, 1995; Goldsmith, 1995 as cited in Mukhija, 2006). Other critics have also suggested that governments need to play a more active role in order to ensure that the newly created jobs are better jobs with higher wages (Schweke, 1995 as cited in Mukhija, 2006).

In the developing countries there is an increasing emphasis on empowering a city, promoting its competitiveness, and fuelling its economic growth (Cities Alliance, 2006a). Experience dictates the need for a complete understanding of local economic conditions, and for the identification of a city's competitive advantages, which are vital in developing effective strategies to promote economic resurgence.

The Cities Alliance-funded CDS provides a methodology for mayors, the private sector, and citizens to develop a sustainable vision for their cities, and a strategy for achieving it. However, in many CDSs, there are still no comprehensive approaches to connect environmental sustainability to economic growth, poverty reduction, and other urban challenges (Cities Alliance, 2006b).

CDSs assume different forms, depending on the location, the context, and the players involved. There are a number of city objectives and themes. For example, as far as themes and contents are concerned, the World Bank and UN-Habitat, two of the most active international agencies preparing and supporting CDSs around the world, have two different definitions of CDS. The World Bank definition focuses on four major themes, namely: livability, competitiveness, good governance, and bankability. Differently, UN-Habitat's definition focuses on five major themes, namely: shelter, social development and eradication of poverty, economic development, governance, and environmental management (ECON \& CLG, UTS, 2005).

Comparing recent CDSs in three metropolitan areas in West Africa, we may get a glimpse of the importance of metropolitan governance for a long-term CDS. Autonomy, jurisdictional and overlapping amendments result into conflicts between districts and cities. There is also a necessity to have a coherent plan to erogate basic services. These aforementioned factors show the importance of metropolitan governance. In such a context, governance is the key theme (Cities Alliance, 2009). Tbilisi' CDS, which was funded by Cities Alliance in 2008, promoted municipal management and governance, the improvement of the economy, the development of a vision for a green city, and equality within a city. This CDS had three major themes, namely business development, governance, and physical plan (Cities Alliance, 2008b). In this CDS, the physical development plan is the major theme as found in other CDSs, such as Amman's (Cities Alliance, 2004b).

Sofia, as a transition city, is a good example of how a city can resolve urban problems through a transition 
economy. The CDS of Sofia focuses on five key themes, namely, the economy, finance, municipal governance, services, and urban infrastructures (Cities Alliance, 2004a).

The contents and themes of CDSs differ from one city to another, depending on the objective of the CDS, the location, and the players involved. There is a wide range of objectives and themes. However, we need a specific definition on the two terms "CDS" and "sustainable urban development" in order to evaluate and compare a CDS's content with the principle of sustainable development.

In this paper we have chosen to employ an early definition of CDS brought forward by the World Bank, along with one of the latest definitions provided by Cities Alliance, in order to assess the commitment of CDS to sustainable development.

The themes of CDSs, based on the World Bank definition, are shown in Figure2.

- $\quad$ Livability

Livability includes poverty reduction, reducing inequality, building a healthy urban environment, increasing personal security, political accountability, and creating recreational facilities that are available to all.

- Competitiveness

Competitiveness builds suitable conditions to create livability. Livability, on the other hand, means providing employment and other sources of income, investment to create them, and an atmosphere of competitiveness. Social equity and security are thus ensured. A city with competitive advantages attracts investments and a good business climate, promotes city products, enhances employment opportunities for the poor, and increases the satisfaction of citizens.

- $\quad$ Good governance and management

Promoting livability and competitiveness relies on accountability and transparency of government, and the participation of citizens. Public responsibility is a product of good governance.

- $\quad$ Bankability

Bankability means sustainable and adequate financial resources, a clear system of local revenues, expenditures, and good financial management. Bankability is financial wholeness, soundness, and creditworthiness, which are necessary for a city to reach a sustainable local finance (The World Bank, 2000).

Figure 3 shows CDSs' themes and contents from Cities Alliance (2006b) as a latest guideline to prepare CDS. These factors have been provided based on the experiences acknowledged during the preparation of $150 \mathrm{CDSs}$ around the world, and on a research carried out in East Asia by ADB \& JBIC and the World Bank (2005); this study emphasizes the importance of infrastructures in pro-poor development and urban competitiveness.

Those five important themes are:

- Livelihood, such as job creation, business development, and sources of household income;

- Environmental sustainability and energy efficiency of the city and the quality of its service delivery;

- Spatial form and infrastructure;

- Financial resources; and

- Governance.

- Livelihood

Livelihood covers three areas, namely, (i) business climate and capacity for creating small-business. The business climate is different in cities, but cities try to attract investment in diverse business climates and sets aside an area to organize small business and business networks; (ii) urban competitiveness. A CDS should determine a comparative and competitive advantage that creates economic clusters to attract investors and thereby achieve economic growth; and (iii) human resource development, which plays a key role in poverty reduction and prevention.

- Environmental sustainability

Environmental sustainability in a CDS process focuses on three areas, namely, i) environmental quality, such as air and water quality, which are important in environmental sustainability; ii) service delivery, including geographical coverage, accessibility, and affordability; and iii) energy efficiency, which affects the welfare of residents.

- $\quad$ Spatial form and infrastructure 
Urban economic competitiveness and the welfare of a city's residents cannot be achieved without the required infrastructures. Spatial form plays a key role in urban decongestion, energy efficiency accessibility, and distribution of services. Therefore, it is essential in poverty reduction.

\section{- Financial resources}

Financial analysis determines how finance resources are spent on infrastructures, public facilities, etc. It creates the atmosphere that attracts private sector funding. Revenue diversity, expenditure regulation, cash-flow management, financial planning, and budgeting are important in a CDS.

\section{- Governance}

Governance plays a key role in CDS because local governments have a close relationship with decision-makers. It is the catalyst between the public and the private sectors, civil society, and the labor market. It helps decrease negative effects on low-income and vulnerable people (Cities Alliance, 2006b).

As mentioned earlier, we chose the World Bank definition and Cities Alliance definitions as two specific definitions to evaluate the commitment of CDS to sustainable development. This selection is because of the World Bank and Cities Alliance definitions employed by many cities worldwide. The definition of CDS was initiated by the World Bank and has been continued by the Cities Alliance's definition in the developing countries; consequently, such definitions are suitable for this comparison.

\section{Comparison between the principle of sustainable urban development and City Development Strategies (CDS)}

In this section, the two definitions of CDS by the World Bank and the Cities Alliance have been compared to a specific definition of sustainable urban development that has been applied by some cities and local governments. As mentioned earlier, Saha and Paterson (2008) combined and completed the viewpoints of three earlier scholars on three areas, namely: environmental protection, economic development, and social equity. Nevertheless, they did not use governance aspects directly in their work. Due to the need of a clear definition of the activities for each aspect of sustainability in order to perform a comparison, by combining Saha and Paterson's work with Portney's, we created a framework with forty-two activities.

The themes and contents of the two definitions of CDS have been compared to the four aspects of sustainable development, namely: environmental protection, economic development, social equity, and governance (as illustrated in Tables 2, 3, 4, and 5).

The definition of CDS postulated by the World Bank has four major themes, namely: livability, competitiveness, good governance and management, and bankability. Livability includes poverty reduction, reducing inequality, building a healthy urban environment, increasing personal security, political accountability, and creating recreational facilities available to all. The components of this theme (livability) cover some parts of environmental protection activities which are found in Table 2, and many activities related to social equity which are presented in Table 4 . However, according to Table 2, the environmental protection dimension is very weak in this definition of CDS, because the key attention of the World Bank's definition focuses mostly on the economic and social aspects. A competitive city with competitive advantages attracts capital investment and creates a good business climate, promotes city products, provides employment, and increases citizen satisfaction. This theme covers activities on economic development which are illustrated in Table 3, along with social equity. Good governance and management create an atmosphere wherein all urban planning stakeholders participate, and performance creates a relationship among and between all levels of government.

The governance aspect of sustainability as presented in Table 5 is fulfilled by this definition of CDS. Bankability means financial sustainability, which is vital in the implementation of a sustainable plan, and which is a factor not taken under consideration by Saha and Paterson (2008) and many other definitions of sustainability.

The Cities Alliance definition of CDS has five key themes, in which livelihood covers three major areas, namely: i) business climate and the capacity for creating small-businesses (creating suitable jobs, especially for low-income and poor people), ii) urban competitiveness (a CDS should determine a comparative and competitive advantage that creates economic clusters) to attract investors and achieve economic growth, and iii) human resource development, that plays a key role in preventing or reducing poverty. This theme covers economic development and social equity of sustainability in Tables 3,4 .

Environmental sustainability and spatial form are two other key themes defined by the Cities Alliance. These include such areas as i) environmental quality, such as air and water quality; ii) service delivery, including geographical coverage, accessibility, and affordability; iii) energy efficiency, which affects the welfare of 
residents; iv) infrastructure; and v) spatial form, which plays a key role in urban congestion, energy efficiency, accessibility, and distribution of services.

This theme covers many activities on environmental protection in Table 2 and some activities on economic development and social equity. Financial resources is another theme defined by Cities Alliance, which is important in the implementation of a sustainable plan. However, as mentioned earlier, it does not take into account the other definitions of sustainability; differently, the governance aspect as postulated by the World Bank's definition covers the governance activities of sustainability.

The comparison between CDS themes and the sustainable urban development aspects demonstrates that early CDSs with the World Bank themes have provided social and economic sustainability. Environmental sustainability is not taken into account in this definition. However, in later CDSs based on the Cities Alliance guidelines, environmental sustainability was a key aspect, and little attention was paid to social sustainability (Figure 4).

\section{Discussion}

This paper has discussed two major definitions of CDS to achieve urban sustainability. These have been issued by the World Bank through the earliest CDSs and the Cities Alliance after 150 experiences of CDS around the world. This comparison between forty-two activities upholding the principle of urban sustainable development on four aspects and themes of two definitions of CDS has demonstrated some important results.

In the late 1990s, the World Bank definition, based on some ideas such as urban good governance, had strictly focused on governance, building capacities of communities and social aspects; on the other hand, it had emphasized on competitive advantages to achieve urban economic development based on Michael Porter's research. The World Bank has employed the CDs to the scope of reducing and alleviating poverty. In order to achieve this aim, the World Bank has focused on governance, capacity building of communities and urban economic development. Therefore, this definition can be seen as successful in order to achieve sustainability in these areas. The principles and activities of sustainability on economic, social and governance can best fulfill this definition and themes of CDS. However, the World Bank definition is very weak in the achievement of environmental sustainability. There are a number of activities related to environmental protection and economic development aspects which are related to environmental sustainability, and they cannot be fulfilled by employing the World Bank definition. This definition of CDS has mirrored the capability to achieve economic and social sustainability, but in real practice, the environmental sustainability has been proven to be unsuccessful.

The Cities Alliance definition of CDS seems to be different. After 150 experiences of CDS worldwide and some studies conducted by international agencies, the environmental sustainability and infrastructures became two major themes in this definition. The key objective in the establishment of CDS by the Cities Alliance is poverty reduction, exactly like in the World Bank's definition. However, the opinions and insights seem to be different. The review and assessment of experiences of CDS demonstrated the importance of urban infrastructures in order to increase poverty reduction in the developing countries. Therefore, in year 2006, the Cities Alliance provided a guideline for the preparation of CDS focused on infrastructures and environmental sustainability. Within this definition and themes of CDS, the role of infrastructures and environmental activities has increased in order to alleviate urban poverty emphasized on social equity and economic development. Thus, the activities related to environmental sustainability can be committed by the Cities Alliance's definition, and this definition can be successful in the fulfillment of environmental sustainability. By contrast, the attention reserved to social activities has decreased. This analysis and comparison has clarified various definitions of CDS, resulting in different forms and proportions of sustainability. In other words, the focus of the CDSs seems to lie solely on one aspect, and there is yet to be a comprehensive approach to connect all aspects of sustainability.

It is obvious that a proper and universally accepted definition of sustainability is vital. Different definitions and components of sustainability result in different outcomes. Bearing this in mind, assessing the relationship between CDS and sustainable urban development is important for individuals in order to know which type of CDS are applicable, and which definition of sustainable urban development is to be used as an adequate measure of sustainability.

\section{Conclusion}

The purpose of this paper is to assess the proportion of sustainable urban development's achievement by using two specific definitions of CDS. This study demonstrates that different definitions will contemplate a diverse level of sustainability. The World Bank's definition focuses on the economic, social and governance aspects, while the Cities Alliance's definition emphasizes on the environmental aspect, and tries to reduce urban poverty. 
However, sustainability is an integrated balance between all the aspects of the economic, social, environment, and governance working. Therefore, both definitions of CDS cannot build an integrated sustainable urban development, and each of them is seen to be successful in some aspects. Therefore, we can deduce that there is still no thorough definition of CDS demonstrating a balance between all aspects of sustainability, and having the capability to build a sustainable city as a whole.

\section{References}

Abu-Ghazalah, S. (2008). The Sustainable City Development Plan for Aqaba, Jordan. Journal of Developing Societies, 24, 381-398. DOI: 10.1177/0169796X0802400304, http://dx.doi.org/10.1177/0169796X0802400304

Asian Development Bank(ADB). (2004). CITY DEVELOPMENT STRATEGIES TO REDUCE POVERTY. Manila: the Asian Development Bank.

Asian Development Bank(ADB), the World Bank(WB), \& Japan Bank For International Cooperation (JBIC). (2005). Connection East Asia: A New Framework for Infrastructure. Washington D.C.: World Bank.

Beall, J. (2002). Globalization and social exclusion in cities: framing the debate with lessons from Africa and Asia. Environment and urbanization, 14(1), 41-51.

Cities Alliance. (2000). Making Cities Work for All: Global Action Plan for City Development Strategies Retrieved from http://www.citiesalliance.com

Cities Alliance. (2004). Annual Report. Washington D.C.

Cities Alliance. (2004b). Greater Amman Development Strategy. Amman: Greater Amman Municipality, the World Bank (MNC02),World Bank (MNSIF),AUDI,GTZ.

Cities Alliance. (2005). 2005 Annual report.

Cities Alliance. (2006a). 2006 Annual Report.

Cities Alliance. (2006b). Guide to City Development Strategies: Improving Urban Performance Washington D.C.: The Cities Alliance.

Cities Alliance. (2008). Submission of proposal: Tbilisi City Development Strategy for Sustainable Development. Tbilisi, Gorgia: Cities Alliance.

Cities Alliance. (2009). 2009 Annual Report.

Conroy, M. M. (2006). Moving the middle ahead: Challenges and opportunities of sustainability in Indiana, Kentucky, and Ohio. Journal of Planning Education and Research, 26, 18-27. DOI: 10.1177/0739456X06289664, http://dx.doi.org/10.1177/0739456X06289664

Diamantine, C., \& Zanon, B. (2000). Planning the urban sustainable development The case of the plan for the province of Trento, Italy. Environmental Impact Assessment Review 20, 299-310.

ECON Analysis, \& Centre for Local Government, U., Sydney. (2005). The Impacts of City Development Strategies. Oslo Broadway.

Healey, P. (2004). The treatment of space and place in the new strategic spatial planning in Europe. International Journal of Urban and Regional Research 28(1), 45-67.

Jepson, E. J. (2001). Sustainability and Planning: Diverse Concepts and Close Associations. Journal of Planning $\begin{array}{llll}\text { Literature, } & 15(4), & 499-510 . & \text { DOI: }\end{array}$ http://dx.doi.org/10.1177/088541220101500401

Jepson, E. J. (2004). The Adoption of Sustainable Development Policies and Techniques in U.S. Cities : How Wide, How Deep, and What Role for Planners? Journal of Planning Education and Research, 23(2), 229-241. DOI: $10.1177 / 0739456 X 03258638$

Keivani, R. (2010). A review of the main challenges to urban sustainability. International Journal of Urban Sustainable Development 1,15-16.doi:10.1080/19463131003704213, http://dx.doi.org/10.1080/19463131003704213

Kim, K.-H. (2002). China CDS Performance Indicators: Final Report: UN-Habitat Fukuoka Office.

Malkina-Pykh, I. G. (2002). Integrated assessment models and response function models: pros and cons for sustainable development indices design. Ecological Indicators, 2, 93-108.

Mukhija, V. (2006). Viewpoint Challenges for international development planning: Preliminary lessons from the 
case of the Cities Alliance. Cities, 23, 56-62.

Porter, M. (1995). The competitive advantage of the inner city. Harvard Business Review, 73, 55-71.

Portney, K. E. (2003). Taking sustainable cities seriously: Economic development, the environment, and quality of life in American cities. Cambridge: MIT Press.

Rotmansa, J., Asselt, M. v., \& Vellinga, P. (2000). An integrated planning tool for sustainable cities. Environmental Impact Assessment Review, 20, 265-276.

Roy, M. (2009). Planning for sustainable urbanization in fast growing cities: Mitigation and adaptation issues addressed in Dhaka, Bangladesh. Habitat International, 33, 276-286. DOI:10.1016/j.habitatint.2008.10.022, http://dx.doi.org/10.1016/j.habitatint.2008.10.022

Saha, D., \& Paterson, R. G. (2008). Local Government Efforts to Promote the "Three Es" of Sustainable Development Survey in Medium to Large Cities in the United States. Journal of Planning Education and Research, 28, 21-37. DOI: 10.1177/0739456X08321803, http://dx.doi.org/10.1177/0739456X08321803

Shen, L.-Y., Jorge Ochoa, J., Shah, M. N., \& Zhang, X. (2011). The application of urban sustainability indicators - A comparison between various practices. Habitat International, 35(1), 17-29. DOI:10.1016/j.habitatint.2010.03.006, http://dx.doi.org/10.1016/j.habitatint.2010.03.006

Spangenberg, J. H., Pfahl, S., \& Deller, K. (2002). Towards indicators for institutional sustainability: lessons from an analysis of Agenda 21. Ecological Indicators, 2, 61-77.

The World Bank. (2000). Cities in Transition. Washington, D.C.: The International Bank for Reconstruction and Development / THE WORLD BANK.

Tonami, A., \& Mori, A. (2007). Sustainable Development in Thailand Lessons From Implementing Local Agenda 21 in Three Cities. The Journal of Environment Development, 16, 269-289. DOI: 10.1177/1070496507306223, http://dx.doi.org/10.1177/1070496507306223

UNDP. (2003). Annual Report 2003. Washington D.C.: UNDP.

UN-Habitat. (2001). Cities in a globalization world: Global report on human settlement. London: Earth scan.

UN-HABITAT. (2009). GLOBAL Report on Human Settlements 2009: Planning Sustainable Cities, London: Earth scan.

Watson, V. (2009). The planned city sweeps the poor away. . '§: Urban planning and 21st century urbanization, ProgressinPlanning72,151-193.DOI:10.1016/j.progress.2009.06.002,

http://dx.doi.org/10.1016/j.progress.2009.06.002

Whitehead, M. (2003). (Re)Analyzing the Sustainable City: Nature, Urbanization and the Regulation of Socio-environmental Relations in the UK. Urban Studies, 40, 1183-1206. DOI: 10.1080/0042098032000084550, http://dx.doi.org/10.1080/0042098032000084550 
Table 1. Sustainable development activities

\begin{tabular}{|c|c|c|c|}
\hline Portney (2003) & Jepson (2004) & Conroy (2006) & Saha \& Paterson (2008) \\
\hline \multicolumn{4}{|l|}{ Environmental protection } \\
\hline \multirow{24}{*}{$\begin{array}{l}\text { 1. Alternative energy sources (solar, wind, } \\
\text { biogas, etc.) } \\
\text { 2. Energy conservation effort } \\
\text { (other than green building program) } \\
\text { 3. Green building program } \\
\text { 4. Renewable energy use by city government } \\
\text { 5. Water conservation program } \\
\text { 6. Household solid waste recycling } \\
\text { 7. Industrial recycling } \\
\text { 8. Hazardous waste recycling } \\
\text { 9. Air pollution reduction program } \\
\text { (i.e., VOC reduction) } \\
\text { 10. Recycled product purchasing by city } \\
\text { government } \\
\text { 11. Superfund site remediation } \\
\text { 12. Asbestos abatement program } \\
\text { 13. Lead paint abatement program } \\
\text { 14. Comprehensive land-use plan that } \\
\text { includes environmental issues } \\
\text { 15. Zoning, to delineate environmentally } \\
\text { sensitive growth areas } \\
\text { 16. Alternatively fueled city vehicle program } \\
\text { 17. Bicycle ridership program } \\
\text { 18. Car pool lanes } \\
\text { 19. Limits on downtown parking spaces } \\
\text { 20. Operation of inner-city public transit } \\
\text { (buses and/or trains) } \\
\text { 21. Indicators project, active for the past five } \\
\text { years }\end{array}$} & 1. Environmental site design & \multirow{33}{*}{$\begin{array}{l}\text { 1. Energy conservation } \\
\text { 2. Green building efforts } \\
\text { 3.Recyclingand } \\
\text { waste minimization } \\
\text { 4. Polluters pay program } \\
\text { 5. Conservation of natural resources } \\
\text { 6. Pedestrian oriented development } \\
\text { 7.Promoting alternative transportation }\end{array}$} & \multirow{33}{*}{$\begin{array}{l}\text { 1. Alternative energy } \\
\text { 2. Energy conservation effort } \\
\text { (other than green building requirements) } \\
\text { 3. Environmental site design regulations } \\
\text { 4. Green building program } \\
\text { 5. Renewable energy use by city } \\
\text { government } \\
\text { 6. Curbside recycling program } \\
\text { 7. Environmental education programs for } \\
\text { the community } \\
\text { 8. Green procurement } \\
\text { 9. Water quality protection } \\
\text { 10. Environmentally sensitive area } \\
\text { protection } \\
\text { 11. Open-space preservation program } \\
\text { 12. Operation of inner-city public transit } \\
\text { (buses and/or trains) } \\
\text { 13. Transportation demand management } \\
\text { 14. Ecological footprint analysis }\end{array}$} \\
\hline & regulations & & \\
\hline & & & \\
\hline & 2. Green building requirements & & \\
\hline & & & \\
\hline & 3. Heat island analysis & & \\
\hline & & & \\
\hline & 4. Rehabilitation building codes & & \\
\hline & & & \\
\hline & 5. Solar access protection regulations & & \\
\hline & & & \\
\hline & 6. Urban forestry program & & \\
\hline & 7. Wind energy development & & \\
\hline & & & \\
\hline & 8. Green procurement & & \\
\hline & & & \\
\hline & 9. Lifecycle public construction & & \\
\hline & 10. Low-emission vehicles & & \\
\hline & 11. Solid waste lifecycle management & & \\
\hline & 12. Green maps & & \\
\hline & & & \\
\hline & 13. Green print plans & & \\
\hline & 14. Greenways development & & \\
\hline & 15. Open-space zoning & & \\
\hline \multirow{9}{*}{$\begin{array}{l}\text { 22. Indicators progress report for the past } \\
\text { five years } \\
\text { 23. Does indicators project include action } \\
\text { plan of policy programs? }\end{array}$} & & & \\
\hline & $\begin{array}{l}\text { 16. Wildlife habitat/green corridor } \\
\text { planning }\end{array}$ & & \\
\hline & 17. Bicycle access plan & & \\
\hline & 18. Pedestrian access plan & & \\
\hline & 19. Transit-oriented development & & \\
\hline & 20. Transportation demand & & \\
\hline & management & & \\
\hline & 21. Ecological footprint analysis & & \\
\hline & 22. Urban ecosystem analysis & & \\
\hline \multicolumn{4}{|l|}{ Economic Development } \\
\hline \multirow{14}{*}{$\begin{array}{l}\text { 24. Brownfield redevelopment } \\
\text { (project or pilot project) } \\
\text { 25. Cluster or targeted economic } \\
\text { development } \\
\text { 26. Eco-industrial park development } \\
\text { 27. Eco-village project or program } \\
\text { 28. Tax incentives for environmentally } \\
\text { friendly development }\end{array}$} & 23. Agricultural district provisions & \multirow{14}{*}{$\begin{array}{l}\text { 8. Brownfield reuse or infill } \\
\text { 9. Environmental constraints } \\
\text { 10. Mixed-use or compact development } \\
\text { 11. Recruiting green industries } \\
\text { 12.Encouraging local employment }\end{array}$} & \multirow{14}{*}{$\begin{array}{l}\text { 15. Agricultural protection zoning } \\
\text { 16. Brownfield reclamation } \\
\text { 17. Cluster or targeted economic } \\
\text { development } \\
\text { 18. Eco-industrial park development } \\
\text { 19. Infill development } \\
\text { 20. Purchase of Development Rights } \\
\text { and/or Transfer of Development Rights } \\
\text { 21. Tax incentives for environmentally } \\
\text { friendly development } \\
\text { 22. Urban growth boundary and/or urban } \\
\text { service boundary } \\
\text { 23. Business retention programs } \\
\text { 24. Empowerment/enterprise zones } \\
\text { 25. Local business incubator programs }\end{array}$} \\
\hline & & & \\
\hline & 24. Agricultural protection zoning & & \\
\hline & 25. Brownfield reclamation & & \\
\hline & & & \\
\hline & 26. Eco-industrial park & & \\
\hline & 27. Infill development & & \\
\hline & 28. Neo-traditional development (also & & \\
\hline & known as traditional neighborhood & & \\
\hline & development and smart development) & & \\
\hline & & & \\
\hline & 29. Purchase of Development Rights & & \\
\hline & 30. Right-to-farm legislation & & \\
\hline & 31. Transfer of Development Rights & & \\
\hline
\end{tabular}




\begin{tabular}{|c|c|c|c|}
\hline & $\begin{array}{l}\text { 32. Urban growth boundary } \\
\text { 33. Import substitution } \\
\text { 34. Tax base/revenue sharing }\end{array}$ & & \\
\hline \multicolumn{4}{|l|}{ Social Equity } \\
\hline & $\begin{array}{l}\text { 35.Community indicators program } \\
\text { 36. Community gardening } \\
\text { 37. Cooperative housing } \\
\text { 38. Incentive/inclusionary zoning } \\
\text { 39. Living wage ordinance }\end{array}$ & 13. Affordable housing & $\begin{array}{l}\text { 26. Affordable housing provisions } \\
\text { 27. Daycare services for service sector } \\
\text { and low-income employees } \\
\text { 28. Homeless prevention and intervention } \\
\text { programs } \\
\text { 29. Inclusionary and incentive zoning } \\
\text { 30. Jobs-housing balance } \\
\text { 31. Living wage ordinance } \\
\text { 32. Mass transit access, with local income } \\
\text { subsidies } \\
\text { 33. Neighborhood planning } \\
\text { 34. Sustainable food systems or food } \\
\text { security programs } \\
\text { 35. Women-/minority-oriented business, } \\
\text { Community Development Corporations } \\
\text { (CDCs), and investment programs } \\
\text { 36. Youth opportunity and anti-gang } \\
\text { programs }\end{array}$ \\
\hline \multicolumn{4}{|l|}{ Governance } \\
\hline $\begin{array}{l}29 \text {. Single governmental/nonprofit agency } \\
\text { responsible for implementing sustainability }\end{array}$ & & $\begin{array}{l}\text { 14. Dispute resolution } \\
\text { 15. Public participation } \\
\text { 16. Regional coordination }\end{array}$ & \\
\hline \multicolumn{4}{|l|}{$\begin{array}{l}\text { 30. Part of a citywide comprehensive plan } \\
\text { 31. Involvement of city/county/metropolitan } \\
\text { council }\end{array}$} \\
\hline \multicolumn{4}{|l|}{$\begin{array}{l}\text { 32. Involvement of mayor or chief executive } \\
\text { officer }\end{array}$} \\
\hline \multicolumn{4}{|l|}{ 33. Involvement of the business community } \\
\hline $\begin{array}{l}\text { 34. General public involvement in sustainable } \\
\text { cities initiative (public hearings, "visioning" } \\
\text { process, neighborhood groups or associations, } \\
\text { etc.) }\end{array}$ & & & \\
\hline
\end{tabular}

Source: Saha \& Paterson (2008)

Table 2. Comparison between the environmental protection aspect of sustainability and CDS themes

\begin{tabular}{|l|l|l|}
\hline \multicolumn{1}{|c|}{ Environmental Protection } & \multicolumn{1}{c|}{$\begin{array}{c}\text { CDS Themes } \\
\text { Cities Alliance } \\
\text { (2006) }\end{array}$} & $\begin{array}{c}\text { CDS Themes } \\
\text { The World Bank } \\
\text { (2000) }\end{array}$ \\
\hline 1. Alternative energy offered & $\checkmark$ & \\
\hline 2. Energy conservation effort (other than green building requirements) & $\checkmark$ & \\
\hline 3. Environmental site design regulations & $\checkmark$ & \\
\hline 4. Green building program & & \\
\hline 5. Renewable energy used by city government & $\checkmark$ & \\
\hline 6. Curbside recycling program & & \\
\hline 7. Environmental education programs for the community & $\checkmark$ & $\checkmark$ \\
\hline 8. Green procurement & & $\checkmark$ \\
\hline 9. Water quality protection & $\checkmark$ & $\checkmark$ \\
\hline 10. Environmentally sensitive area protection & $\checkmark$ & $\checkmark$ \\
\hline 11. Open-space preservation program & $\checkmark$ & $\checkmark$ \\
\hline 12. Operation of inner-city public transit (buses and/or trains) & $\checkmark$ & \\
\hline 13. Transportation demand management & $\checkmark$ & $\checkmark$ \\
\hline 14. Ecological footprint analysis & $\checkmark$ & \\
\hline
\end{tabular}

$\checkmark \quad$ : relevant (Yes) 
Table 3. Comparison between the economic development aspect of sustainability and CDS themes

\begin{tabular}{|l|l|l|}
\hline Economic Development & $\begin{array}{l}\text { CDS Themes } \\
\text { Cities Alliance } \\
\text { (2006) }\end{array}$ & $\begin{array}{l}\text { CDS Themes } \\
\text { World Bank }\end{array}$ \\
\hline 15. Agricultural protection zoning & $\checkmark$ & $\checkmark$ \\
\hline 16. Brownfield reclamation & $\checkmark$ & $\checkmark$ \\
\hline 17. Cluster or targeted economic development & & \\
\hline 18. Eco-industrial park development & $\checkmark$ & \\
\hline 19. Infill development & $\checkmark$ & \\
\hline $\begin{array}{l}\text { 20. Purchase of Development Rights and/or Transfer of Development } \\
\text { Rights }\end{array}$ & $\checkmark$ & $\checkmark$ \\
\hline 21. Tax incentives for environmentally friendly development & $\checkmark$ & $\checkmark$ \\
\hline 22. Urban growth boundary and/or urban service boundary & $\checkmark$ & $\checkmark$ \\
\hline 23. Business retention programs & $\checkmark$ & $\checkmark$ \\
\hline 24. Empowerment/enterprise zones & $\checkmark$ & $\checkmark$ \\
\hline 25. Local business incubator programs & & \\
\hline
\end{tabular}

$$
\checkmark \quad \text { : relevant (Yes) }
$$

Table 4. Comparison between the social equity aspect of sustainability and CDS themes

\begin{tabular}{|l|l|l|}
\hline \multicolumn{1}{|c|}{ Social Justice and Equity } & \multicolumn{1}{|c|}{$\begin{array}{c}\text { CDS Themes } \\
\text { Cities Alliance } \\
\text { (2006) }\end{array}$} & \multicolumn{1}{c|}{$\begin{array}{c}\text { CDS Themes } \\
\text { Whorld Bank } \\
\text { (2000) }\end{array}$} \\
\hline 26. Affordable housing provisions & $\checkmark$ & $\checkmark$ \\
\hline $\begin{array}{l}\text { 27. Daycare services for the service sector and low-income } \\
\text { employees }\end{array}$ & $\checkmark$ & $\checkmark$ \\
\hline 28. Homeless prevention and intervention programs & $\checkmark$ & $\checkmark$ \\
\hline 29. Inclusionary and incentive zoning & $\checkmark$ & $\checkmark$ \\
\hline 30. Jobs-housing balance & $\checkmark$ & $\checkmark$ \\
\hline 31. Living wage ordinance & $\checkmark$ & $\checkmark$ \\
\hline 32. Mass transit access, with local income subsidies & $\checkmark$ & $\checkmark$ \\
\hline 33. Neighborhood planning & $\checkmark$ & $\checkmark$ \\
\hline 34. Sustainable food systems or food security programs & & \\
\hline $\begin{array}{l}\text { 35. Women/minority-oriented business, Community } \\
\text { Development Corporations (CDCs), and investment } \\
\text { programs }\end{array}$ & & $\checkmark$ \\
\hline 36. Youth opportunity and anti-gang programs & & $\checkmark$ \\
\hline
\end{tabular}

$$
\checkmark \quad \text { : relevant (Yes) }
$$


Table 5. Comparison between the governance aspect of sustainability and CDS themes

\begin{tabular}{|l|l|l|}
\hline Governance & $\begin{array}{l}\text { CDS Themes } \\
\text { Cities Alliance } \\
\text { (2006) }\end{array}$ & $\begin{array}{l}\text { CDS Themes } \\
\text { The World Bank } \\
\text { (2000) }\end{array}$ \\
\hline $\begin{array}{l}\text { 37. Single governmental/nonprofit agency } \\
\text { responsible for }\end{array}$ & $\checkmark$ & $\checkmark$ \\
\hline $\begin{array}{l}\text { 38. Part of a citywide comprehensive plan } \\
\text { 39. Involvement of city/county/ metropolitan council }\end{array}$ & $\checkmark$ & $\checkmark$ \\
\hline $\begin{array}{l}\text { 40. Involvement of mayor or chief executive officer } \\
\text { 41. Involvement of the business community }\end{array}$ & $\checkmark$ & $\checkmark$ \\
\hline $\begin{array}{l}\text { 42. General public involvement in sustainable cities' } \\
\text { initiatives (public hearings, "visioning" process, } \\
\text { neighborhood groups or associations, etc.) }\end{array}$ & $\checkmark$ & $\checkmark$ \\
\hline
\end{tabular}

$\checkmark \quad$ : relevant (Yes)

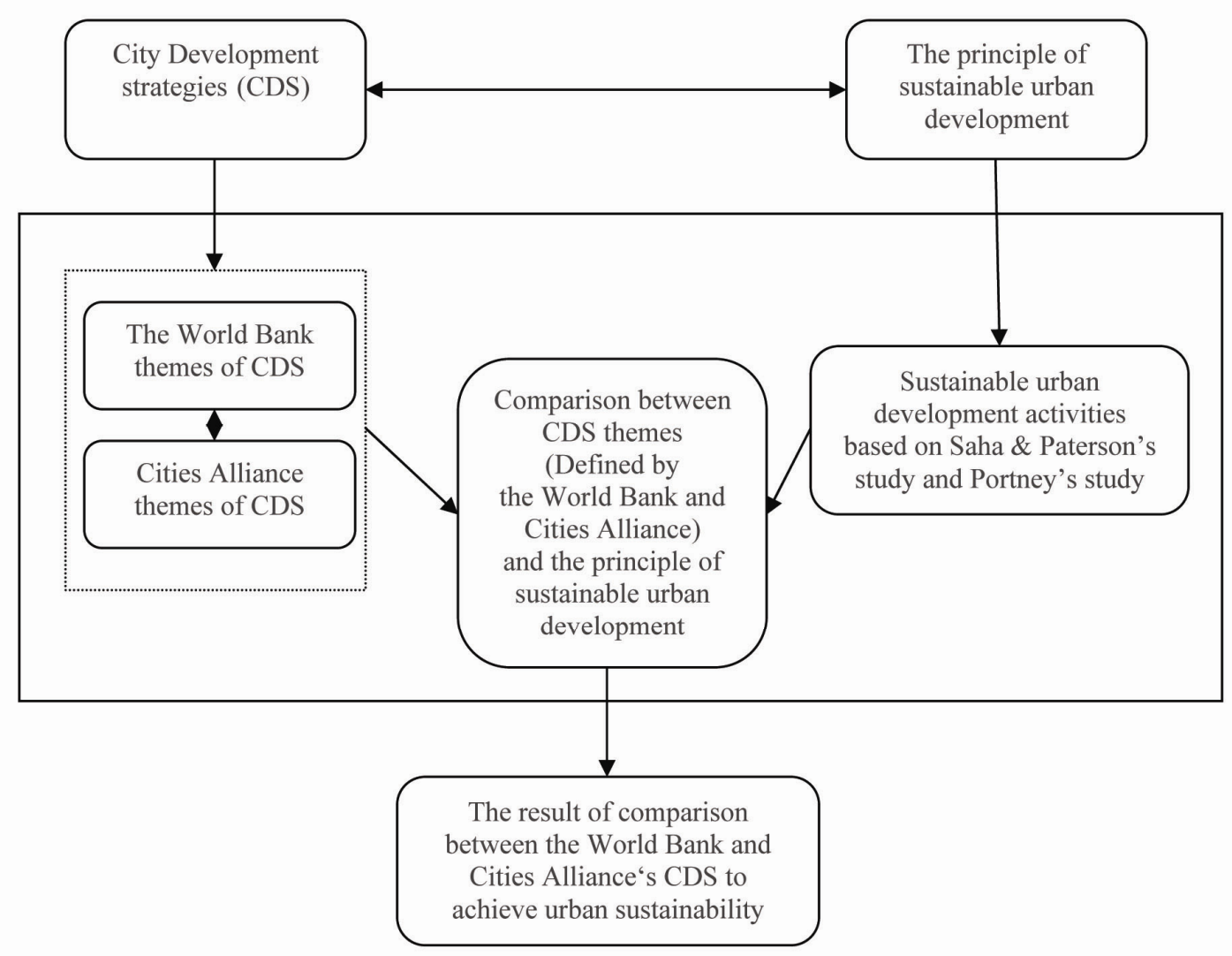

Figure 1. The Flowchart of research 


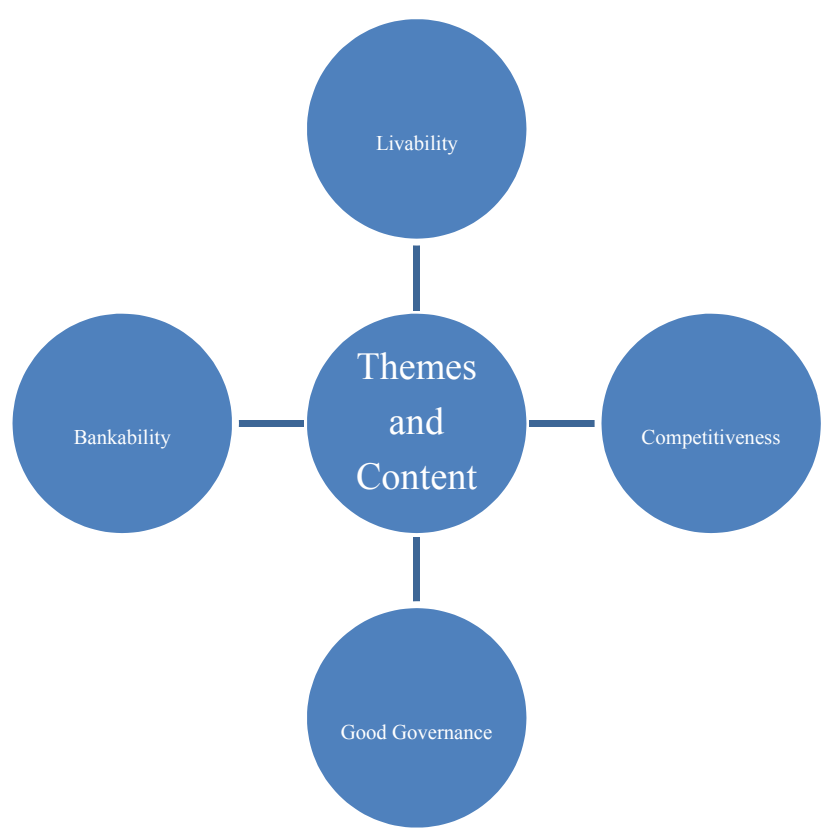

Figure 2. CDS themes based on the World Bank definition Source: The World Bank (2000)

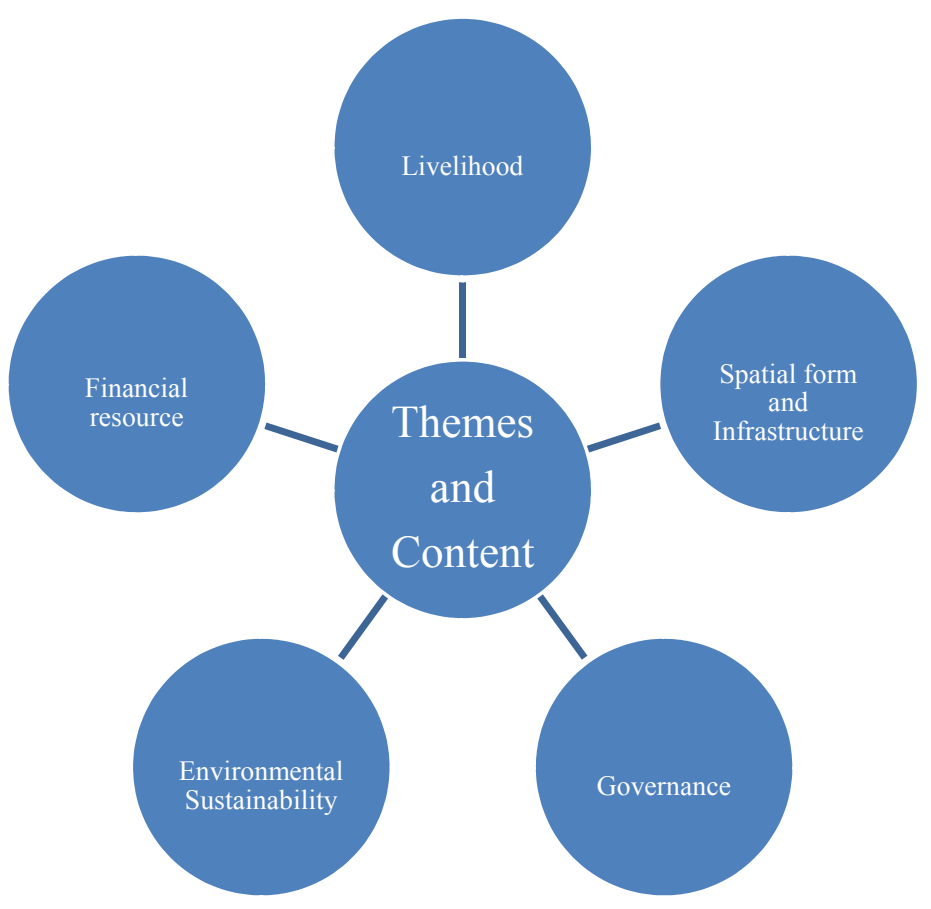

Figure 3. CDS themes based on Cities Alliance definition Source: Cities Alliance (2006b) 


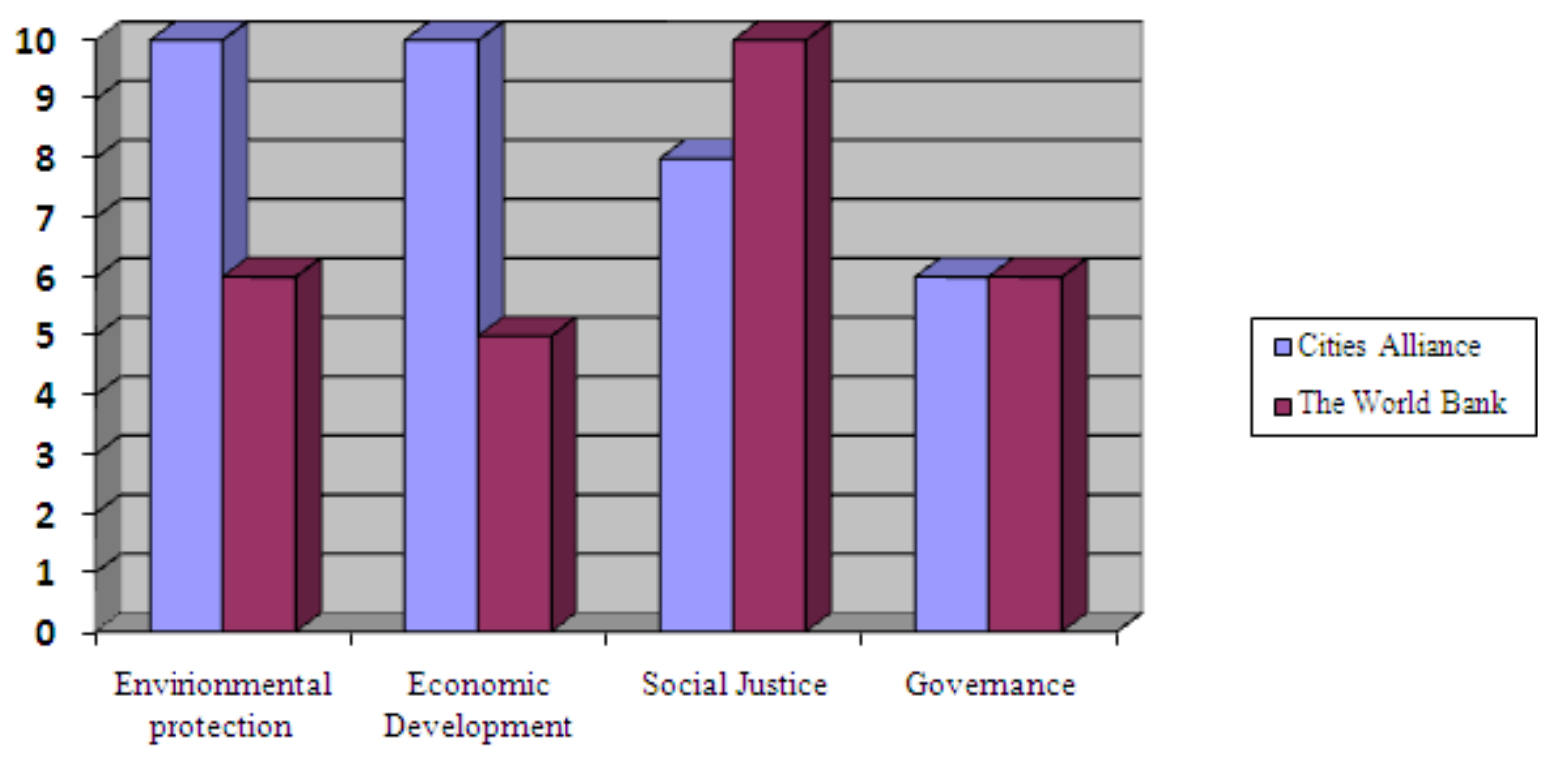

Figure 4. The result of comparison CDS themes and the principles of sustainable urban development 